\title{
Occupational exposure and 12-year spirometric changes among Paris area workers
}

\author{
F KAUFFMANN, ${ }^{2}$ D DROUET, ${ }^{1}$ J LELLOUCH, ${ }^{2}$ AND D BRILLE ${ }^{1}$
}

From the Unité de Recherches de Physiopathologie respiratoire de l'INSERM.(U68), ${ }^{1}$ Paris, and the Unité de Recherches sur les Méthodes Statistiques et Epidémiologiques et leurs applications à l'étude des Maladies Chroniques INSERM (U169)2, Villejuif, France

ABSTRACT A follow-up study over 12 years was conducted among 556 men aged 30 to 54 in 1960 and working at that time in factories around Paris (France). Various occupational exposures were recorded at the time of the 1960 survey after a technical study of each workplace. The annual rate of decline of $\mathrm{FEV}_{1}$ during 12 years was estimated for each subject from the measurements in

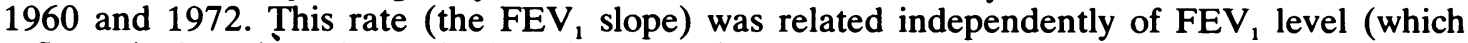
reflects the loss since the beginning of adult life) and of smoking habits to occupational exposure to dust, gases, and heat. $\mathrm{FEV}_{1}$ slope was significantly related to inhalation of mineral dust (even in the absence of silica) as well as to grain dust, and the slope was steeper with increased intensity of exposure to dust. Analysis of job changes showed that among heavily exposed subjects, those who changed jobs had a less steep slope than those who did not. Our results support the hypothesis of a causal role of exposure to dust in the development of chronic airflow obstruction and of a benefit when exposure to dust ceases. Exposure to dust, gas, and heat usually occurred together so data on gas and heat were analysed after taking account of exposure to dust. The influence of heat on $\mathrm{FEV}_{1}$ decline showed a clear trend. Results suggest that exposure to gases associated with exposure to dust or heat or both had a deleterious effect. After adjusting for age, smoking, and $\mathrm{FEV}_{1}$ level (ASLA) the following average slopes were obtained: $44 \mathrm{ml} / \mathrm{a}$ (for exposure to none or to only a slight amount of dust, or to gases alone), $51 \mathrm{ml} / \mathrm{a}$ (heat), $53 \mathrm{ml} / \mathrm{a}$ (noticeable dust), $55 \mathrm{ml} / \mathrm{a}$ (noticeable dust and heat), $60 \mathrm{ml} / \mathrm{a}$ (noticeable dust, heat, and high concentration of gases). Independently of the occupational exposures, ASLA FEV ${ }_{1}$ slopes among manual workers were related to skill, being $44 \mathrm{ml} / \mathrm{a}$ for skilled and $51 \mathrm{ml} / \mathrm{a}$ for unskilled men. Independently of social class and occupational exposures recorded, there were differences in $\mathrm{FEV}_{1}$ slopes by factory, suggesting that one should not rely on using one factory as the control for studies of occupational exposure to another.

Tobacco is at present the only respiratory irritant whose causal role in the development of chronic airflow obstruction (CAO) is unquestioned. This is not the case for occupational irritants, studied principally in cross-sectional surveys conducted among people at work and therefore likely to have been selected. ${ }^{1}$

In a follow-up study we have shown that the annual decline of forced expiratory volume in one second $\left(F E V_{1}\right)$ was related, independently of smoking, to low occupational status and to occupational

Requests for reprints: F Kauffmann, Inserm U169, 16 bis av PV Couturier, F-94800, Ville juif.

Received 17 July 1980

Accepted 15 June 1981 exposure. ${ }^{2}$ About 30 different hazards were recorded, but that analysis was based only on the presence or absence of occupational exposure, regardless of its nature. The purpose of the present work is to determine to which of these 30 specific exposures $\mathrm{FEV}_{1}$ slope was related and to what extent this relationship was causal.

\section{Material and methods}

The detailed study protocol has been published elsewhere. ${ }^{2}$ In a first survey conducted in $1960-1^{3}$ men aged 30 to 54 working in 11 factories (metallurgy, chemistry, printing, and flour-milling) in the Paris area were interviewed about their symptoms, 
smoking habits, and occupational history. Concomitantly, a technical study by engineers and industrial physicians allowed the assessment of the risks of each work place. "Physical" risks, such as heat or work out of doors, and "chemical" risks were considered: the list of chemical hazards, established before this survey, included various dusts (mineral, plant dust, etc) and various gases (acids etc). The level of exposure was recorded at four levels for dusts (slight, noticeable-degrees 1,2, and 3) and two levels for gases (low or high: high was defined as exposure without protection for more than one hour a week). Each subject was assigned to one of four socio-occupational classes-managers, clerks, skilled, and unskilled manual workers.

In a second survey, conducted in 1972-3, the same men were interviewed with the BMRC/ECSC (British Medical Research Council/European Coal and Steel Community) questionnaire about their symptoms, smoking habits, and job changes. With respect to job changes three groups were defined: men with no change in workplace during the 12 years or until their retirement at 65 , men who changed workplace, occupation, or company before age 65 for other than medical reasons, and, finally, those who changed jobs or stopped working permanently for medical reasons. No data about exposure were recorded in the second survey.

In both surveys spirographic measurements were performed with a water spirograph. The maximum values of vital capacity and $\mathrm{FEV}_{1}$ were used for analysis. The quality of the tracings was recorded.

The population of the study was defined as follows: men born in France or abroad (except in North Africa, because of a high lapse rate) who, in 1960 , produced good tracings with no history of asthma. Among the 1002 men fulfilling these criteria, 107 had died during the 12-year interim and $780(87 \%)$ of the men not known to be dead, were re-examined. The refusal rate varied significantly among factories (from $2 \%$ to $17 \%$ ) but was not related to exposure to any particular hazard or to socio-occupational class. Among these $\mathbf{7 8 0}$ men, only 556 (of whom $10 \%$ were not still working, half for medical reasons) produced in 1972 a good tracing. ${ }^{4}$ The results presented here concern these men. The men with bad tracings in 1972 had exposure similar to those with good ones.

For each man, $\mathrm{FEV}_{1}$ slopes (and $\mathrm{VC}$ and $\mathrm{FEV}_{1} /$ VC slopes) was estimated by the formula

$$
\begin{aligned}
& \mathrm{FEV}_{1} \text { slope }(\mathrm{ml} / \text { year })= \\
& \frac{12\left(\mathrm{FEV}_{1} \text { in } 1960-\mathrm{FEV}_{1} \text { in } 1972\right)}{\text { months between } 2 \text { surveys }}
\end{aligned}
$$

To avoid the interference of regression toward the mean, FEV and $\mathrm{VC}$ levels (divided by the cube of height) and $\mathrm{FEV}_{1} / \mathrm{VC}$ level during the study were estimated by the average of the initial and final values, not by the initial one.

The 23 hazards to which at least five men were exposed were analysed.

The relationship between the variables was evaluated by $\chi^{2}$ for qualitative variable and by the analysis of variance and covariance, and multiple regression for the quantitative variables.

\section{Results}

\section{FACTORIES AND HAZARDS}

Table 1 gives for each of the 11 factories the means of age, $\mathrm{FEV}_{1}$ in $1960, \mathrm{FEV}_{1} / \mathrm{H}^{3}$ level during the period and FEV, slopes crude and adjusted for age, 1960 smoking habits, and $\mathrm{FEV} \mathrm{V}_{1} / \mathrm{H}^{3}$ level (age, smoking, level adjusted). Whereas $F E V_{1}$ level did not vary significantly from one factory to another, the difference in slopes was significant from one factory to another at the 0.001 level. In the 11 factories $10 \%$ of the subjects were exposed to silica and $68 \%$ to at least one potentially hazardous factor (the percentage varied from $49 \%$ to $81 \%$ ).

Table 2 compares the non-exposed men to those exposed to the various hazards for age, $\mathrm{FEV}_{1}$ level and FEV, slope. The percentage of men exposed to at least one hazard was $58 \%$ of non-smokers, $73 \%$ of ex-smokers, $65 \%$ of moderate smokers $(<15 \mathrm{~g} /$ day), and $74 \%$ of heavy smokers $(p=0 \cdot 07)$. Because of this trend and though no hazard, considered separately, was significantly related to tobacco consumption in 1960, adjustment for 1960 smoking habits are also shown in the ASLA slopes. The only significant differences in FEV, levels were for abrasives and coal; for silica, the difference was borderline $(p=0.08)$. Men exposed to maize powder had a higher level but the difference was completely explained by difference in age. By contrast, FEV slope was more strongly related to occupational exposure, since men exposed to mineral dust, plant dust, gases, or heat had significantly steeper slopes than the non-exposed $(52 \mathrm{ml} / \mathrm{a}, 57 \mathrm{ml} / \mathrm{a}, 47 \mathrm{ml} / \mathrm{a}$, and $55 \mathrm{ml} / \mathrm{a}$ respectively against $40 \mathrm{ml} / \mathrm{a}$ ).

More precisely, the data show that:

(a) among mineral dusts, exposure to silica, abrasives (possibly including silica), coal, and iron was associated with significantly steeper slopes before and after adjustment (except for abrasives, which were of borderline significance);

(b) among plant dusts, slopes were particularly steep for men exposed to grain dust;

(c) among gases, vapours, and aerosols, exposure to non-halogenated hydrocarbons and oil of turpentine was significantly related to FEV, slope; for nit- 
Table 1 Age, ventilatory function, occupational exposure, and socio-occupational class according to industrial sector and factory

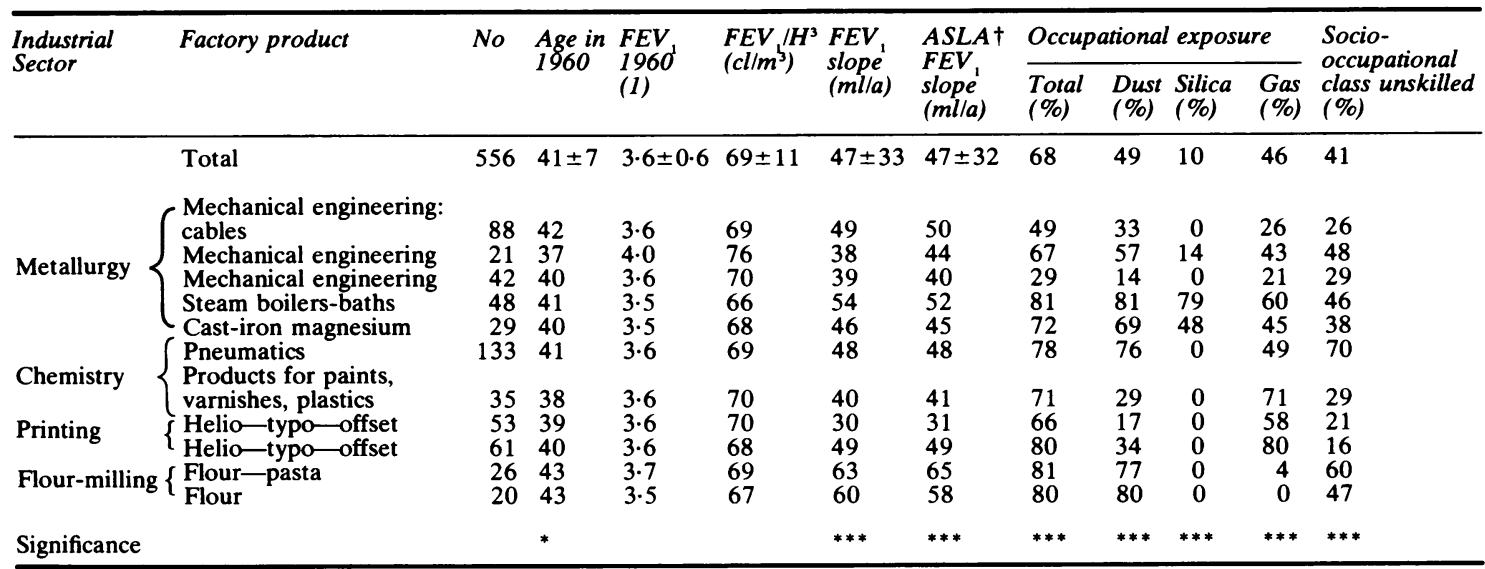

$* p \leqslant 0.05, * * * \leqslant 00.001$.

†Age, 1960 smoking habits (non-smokers: 0 , ex-smokers: 1 , smokers $\leqslant 15$ g/day: 2 , heavy smokers: 3 ) and $\mathrm{FEV}_{1} / \mathrm{H}^{3}$ level adjusted. Regressions used were established on the whole population (556 men).

Table 2 Age, ventilatory function according to occupational exposure

\begin{tabular}{|c|c|c|c|c|c|}
\hline Occupational exposure & No & Age & $\begin{array}{l}F E V_{1 / H^{3}} \\
\left(\mathrm{cl} / \mathrm{m}^{3}\right)\end{array}$ & $\begin{array}{l}\text { FEV } \\
(\mathrm{ml} / \mathrm{a})\end{array}$ & $\begin{array}{l}\text { ASLA } \dagger \\
\text { FEV, slope } \\
(m l / a)\end{array}$ \\
\hline $\begin{array}{l}\text { None } \\
\text { At least one hazard }\end{array}$ & $\begin{array}{l}177 \\
379\end{array}$ & $\begin{array}{l}41 \\
41\end{array}$ & $\begin{array}{l}69 \\
69\end{array}$ & $\begin{array}{l}40 \\
50^{* *}\end{array}$ & $\begin{array}{l}42 \\
50^{* *}\end{array}$ \\
\hline $\begin{array}{l}\text { Dust } \\
\text { Mineral dust } \\
\text { Silica } \\
\text { Abrasives (based on silica, corundum) } \\
\text { Coal } \\
\text { Iron (cast-iron, steels, alloys) } \\
\text { Other metals } \\
\text { Other mineral dusts } \\
\text { Plant dust } \\
\text { Grain dust } \\
\text { Maize powder } \\
\text { Others: "house dust" }\end{array}$ & $\begin{array}{r}273 \\
178 \\
55 \\
11 \\
27 \\
34 \\
32 \\
91 \\
58 \\
36 \\
20 \\
45\end{array}$ & $\begin{array}{l}40 \\
41 \\
41 \\
39 \\
41 \\
40 \\
39 \\
41 \\
41 \\
43 \bullet \\
36^{* *} \\
40\end{array}$ & $\begin{array}{l}69 \\
69 \\
66 \bullet \\
62^{* *} \\
65^{*} \\
68 \\
70 \\
70 \\
71 \\
68 \\
75^{*} \\
68\end{array}$ & $\begin{array}{l}51^{* * *} \\
52^{* * *} \\
59^{* * *} \\
62^{* *} \\
63^{* * *} \\
64^{* * * *} \\
42^{* *} \\
52^{* * *} \\
57^{* * *} \\
66^{* * *} \\
43 \\
46\end{array}$ & $\begin{array}{l}51^{* *} \\
52^{* *} \\
57^{* *} \\
58 \bullet \\
60^{* *} \\
63^{* * *} \\
43 \\
53^{* *} \\
58^{* * *} \\
65^{* * *} \\
47 \\
45\end{array}$ \\
\hline $\begin{array}{l}\text { Gases } \\
\text { No protection } \geqslant 1 \text { hour/week } \\
\text { Acids } \\
\text { Nitrogen compounds including nitric acid } \\
\text { Chlorine compounds including hydrochloric acid } \\
\text { Sulphur compounds including sulphuric acid and sulphur }\end{array}$ & $\begin{array}{r}254 \\
90 \\
52 \\
20 \\
13\end{array}$ & $\begin{array}{l}40 \\
40 \\
39 \\
40 \\
40\end{array}$ & $\begin{array}{l}69 \\
69 \\
69 \\
66 \\
70\end{array}$ & $\begin{array}{l}47^{*} \\
47 \bullet \\
43 \\
52 \bullet \\
39\end{array}$ & $\begin{array}{l}47^{*} \\
47 \\
44 \\
50 \\
38\end{array}$ \\
\hline $\begin{array}{l}\text { dioxide } \\
\text { Alkalines } \\
\text { Ammonia } \\
\text { Gum arabic } \\
\text { Alcohols, esters, ketones (and complex solvents) } \\
\text { Non-halogenated hydrocarbons (including tars) } \\
\text { Halogenated hydrocarbons (including trichlorethylene) } \\
\text { Oil of turpentine (and resins, varnishes, paints based on ....) } \\
\text { Plasticisers, phenol, formol (and artificial glues, plastics, }\end{array}$ & $\begin{array}{r}24 \\
17 \\
24 \\
38 \\
65 \\
120 \\
40 \\
47\end{array}$ & $\begin{array}{l}42 \\
38 \\
39 \\
42 \\
41 \\
40 \\
37^{* *} \\
40\end{array}$ & $\begin{array}{l}70 \\
72 \\
67 \\
69 \\
69 \\
69 \\
73 \\
67\end{array}$ & $\begin{array}{l}45 \\
37 \\
48 \\
40 \\
42 \\
49^{*} \\
39 \\
56^{* * *}\end{array}$ & $\begin{array}{l}47 \\
40 \\
46 \\
40 \\
42 \\
49^{*} \\
42 \\
56^{* *}\end{array}$ \\
\hline $\begin{array}{l}\text { synthetic rubber) } \\
\text { Work out of doors } \\
\text { Heat }\end{array}$ & $\begin{array}{l}28 \\
12 \\
79\end{array}$ & $\begin{array}{l}38^{*} \\
41 \\
40\end{array}$ & $\begin{array}{l}73 \\
73 \\
69\end{array}$ & $\begin{array}{l}42 \\
39 \\
55^{* * *}\end{array}$ & $\begin{array}{l}44 \\
39 \\
55^{* * *}\end{array}$ \\
\hline
\end{tabular}

-p $\leqslant 0 \cdot 10,{ }^{*} p \leqslant 0.05,{ }^{* *} p \leqslant 0.01,{ }^{* * *} p \leqslant 0.001$.

Each hazard $v$ no hazard.

tSee footnote table 1 . 
rogen compounds the relationship was of borderline significance.

There was no evidence of interaction between tobacco and the various risks.

\section{DETAILED STUDY OF THE THREE RISKS: DUST,}

GASES, HEAT

The results just given concern hazards considered separately without taking into account possible simultaneous exposures. In fact, as shown in table 3, exposures to dust, gas, and heat were highly related. Sixty three per cent of the men exposed to gases and $91 \%$ of those exposed to heat were also exposed to dust. Each of the three risks was related to the others two by two after adjustment on the third; some combinations appeared to be rare.

Table 3 Combined exposures to dust, gases, heat (number of men)

\begin{tabular}{|c|c|c|c|c|}
\hline & & No & $\begin{array}{c}\text { Dust } \\
\text { slight }\end{array}$ & Noticeable \\
\hline \multicolumn{5}{|l|}{ No heat } \\
\hline \multirow{3}{*}{ Gas } & ( None & 186 & 9 & 96 \\
\hline & Low & 34 & 56 & 24 \\
\hline & \multicolumn{4}{|c|}{ Heat } \\
\hline Met & None & 3 & 2 & 6 \\
\hline \multirow{2}{*}{ Gas } & Low & 4 & 6 & 40 \\
\hline & High & 0 & 3 & 15 \\
\hline
\end{tabular}

Dust

The harmfulness of silica is well known and was confirmed here. The men exposed to mineral dust were reanalysed after excluding those exposed to silica or abrasives. No subject was exposed to coal dust, and only six were exposed to iron dust; the mean $F E V_{1}$ slope of the latter was $47 \mathrm{ml} / \mathrm{a}$, not significantly different from that of the nonexposed men, presumably because of the small number of men considered. For men exposed to "other mineral dust," the difference was still significant. Unfortunately, it was not possible to subdivide this heterogeneous group further because more precise data were not recorded.

The 28 men exposed to grain dust, but not to mineral dust, had on average a steeper slope than the non-exposed men.

All the differences persisted after exclusion of men exposed to gases.

The relationship of level of dust exposure to $\mathrm{FEV}_{1}$ slope was highly significant (table 4). ASLA slopes were $41 \mathrm{ml} / \mathrm{a}$ for non-exposed, $47 \mathrm{ml} / \mathrm{a}$ for men exposed to a slight amount of dust, and respectively $52 \mathrm{ml} / \mathrm{a}, 51 \mathrm{ml} / \mathrm{a}$, and $61 \mathrm{ml} / \mathrm{a}$ for men exposed to a noticeable amount degree 1,2 , and 3 . A similar gradation was found for VC slope. Excluding men exposed to silica and abrasives did not modify these results, although only two men were left in the most exposed group. The last column of the table presents the more homogeneous group of men who were at the work place for the two surveys: ASLA slopes were $39 \mathrm{ml} / \mathrm{a}, 44 \mathrm{ml} / \mathrm{a}, 58 \mathrm{ml} / \mathrm{a}$, and $52 \mathrm{ml} / \mathrm{a}$ (there were no subjects in the heaviest exposure group). These results show that the clearly noxious role of dust appeared when exposure was noticeable.

Table 5 shows that men noticeably exposed decreased or ceased smoking more often than the

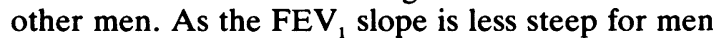
who have decreased their consumption, the relationship between dust exposure and FEV 1 slope could not but be stronger when taking into account changes in smoking habits.

The fact that exposure to dust other than silica was related only to $\mathrm{FEV}_{1}$ slope but not to $\mathrm{FEV}_{1}$ level, which reflects decline before the first survey, appears curious. A possible explanation is that the exposed men were not comparable with the nonexposed at the beginning of their adult life. Figure 1 represents, for the men with no job changes, the evolution of $\mathrm{FEV}_{1}$ between the two surveys accord-

Table 4 Spirometric changes according to the level of dust exposure

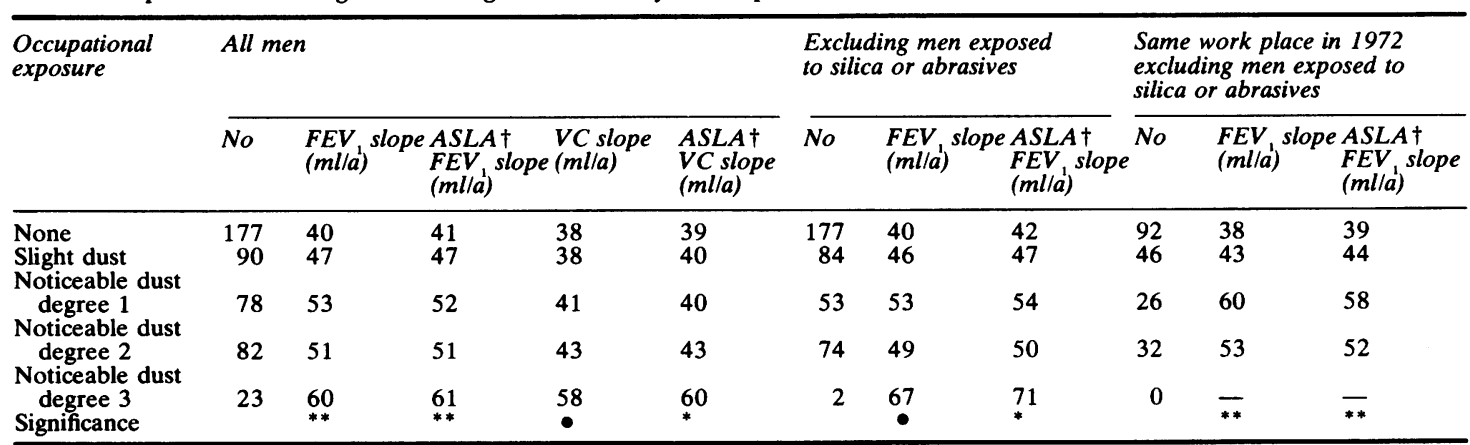

$\bullet p \leqslant 0 \cdot 10,{ }^{*} p \leqslant 0.05,{ }^{* *} p \leqslant 0.01,{ }^{* * *} p \leqslant 0.001$.

†See footnote table 1 . 
Table 5 Decrease in tobacco consumption and job changes between 1960 and 1972 according to occupational exposure in 1960 (manual workers only)

\begin{tabular}{|c|c|c|c|c|c|c|c|}
\hline \multirow[t]{2}{*}{ Occupational exposure in 1960} & \multirow[t]{2}{*}{ No } & \multirow{2}{*}{$\begin{array}{l}\text { Ex-smokers } \\
\text { in } 1960(\%)\end{array}$} & \multirow{2}{*}{$\begin{array}{l}\text { Quit or } \\
\text { decrease } \\
\text { smoking } \\
60-72(\%) \\
{[1]}\end{array}$} & \multicolumn{3}{|c|}{ Job changes 1960-72 } & \multirow{2}{*}[\begin{array}{l}{1}\\
{3}\end{array}]{$\begin{array}{l}\text { or }[2] \text { or } \\
(\%)\end{array}$} \\
\hline & & & & $\begin{array}{l}\text { Respiratory } \\
\text { illnesses (\%) }\end{array}$ & $\begin{array}{l}\text { Medical } \\
\text { reasons (all) } \\
(\%)[2]\end{array}$ & $\begin{array}{l}\text { Other } \\
\text { reasons (\%) } \\
{[3]}\end{array}$ & \\
\hline $\begin{array}{l}\text { All } \\
\text { None } \\
\text { Slight dust } \\
\text { Noticeable dust degree } 1 \\
\text { Noticeable dust degree } 2 \\
\text { Noticeable dust degree } 3 \\
\text { Other hazard } \\
\text { Significance }\end{array}$ & $\begin{array}{r}456 \\
98 \\
81 \\
72 \\
81 \\
23 \\
101\end{array}$ & $\begin{array}{r}12 \\
9 \\
15 \\
8 \\
10 \\
30 \\
11 \\
6\end{array}$ & $\begin{array}{l}17 \\
13 \\
11 \\
18 \\
12 \\
26 \\
26\end{array}$ & $\begin{array}{l}2 \\
2 \\
1 \\
0 \\
3 \\
9 \\
2\end{array}$ & $\begin{array}{r}11 \\
7 \\
6 \\
18 \\
10 \\
22 \\
11 \\
-\end{array}$ & $\begin{array}{l}41 \\
39 \\
39 \\
34 \\
48 \\
48 \\
41\end{array}$ & $\begin{array}{l}59 \\
52 \\
51 \\
61 \\
62 \\
74 \\
63\end{array}$ \\
\hline
\end{tabular}

$\bullet p \leqslant 0 \cdot 10,{ }^{*} p \leqslant 0.05$.

ing to age in 1960 and the level of dust exposure (none or slight against noticeable): at $35, \mathrm{FEV}_{1}$ was clearly higher among exposed men but with age $F E V_{1}$ declines more quickly. A phenomenon of selection or self-selection is evident, with the subjects in better health working or perhaps remaining at the more exposed jobs. Clearly this phenomenon increased with age-men still working at 52 years, especially at exposed places, were selected subjects of their age group.

In summary (1) men exposed to dust, even without exposure to silica, had steeper slopes than the non-exposed independently of tobacco consumption, (2) this decline increased with the level of exposure, and (3) whereas young exposed men had higher $F E V_{1} s$ than the non-exposed, the older men had lower FEV 1 s. These results support the causal role of exposure to dust in chronic airflow obstruction.

Gases, vapours, aerosols

Table 6 shows that men exposed to gas do not have steeper slopes than those not exposed, looking separately at the men not exposed and exposed to noticeable dust. Considering the men exposed to a

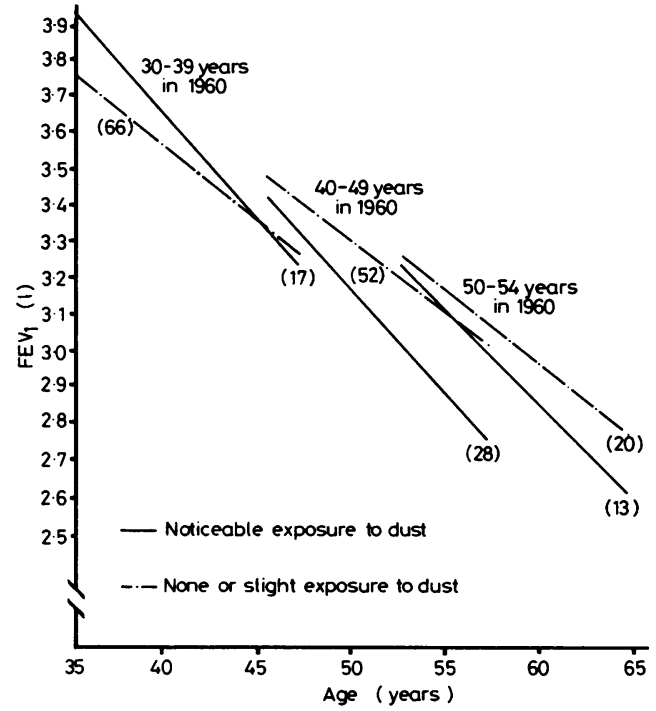

Fig $1 F E V_{1}$ in 1960 and 12 years later according to occupational exposure to dust and age (196 men not exposed to silica or abrasives at the same workplace in 1960 and 1972).

Table 6 Spirometric changes according to gas and exposure (all men)

\begin{tabular}{|c|c|c|c|c|c|c|c|}
\hline & & \multicolumn{6}{|c|}{ Noticeable dust } \\
\hline & & \multicolumn{3}{|l|}{ No } & \multicolumn{3}{|l|}{ Yes } \\
\hline & & No & $\begin{array}{l}F E V_{(m)} \text { slope } \\
\text { mla }\end{array}$ & $\begin{array}{l}\text { ASLA } \dagger \\
\text { FEV slope } \\
(\mathrm{ml} / \mathrm{a})\end{array}$ & No & $\begin{array}{l}\text { FEV slope } \\
\left(\mathrm{ml} / \mathrm{a}^{\prime}\right)\end{array}$ & $\begin{array}{l}A S L A \dagger \\
F E V_{\text {s }} \text { slope } \\
(m l / a)\end{array}$ \\
\hline Gas & $\left\{\begin{array}{l}\text { No } \\
\text { Yes }\end{array}\right.$ & $\begin{array}{l}199 \\
173\end{array}$ & $\begin{array}{l}43 \\
44\end{array}$ & $\begin{array}{l}44 \\
45\end{array}$ & $\begin{array}{r}102 \\
81\end{array}$ & $\begin{array}{l}52 \\
54\end{array}$ & $\begin{array}{l}53 \\
53\end{array}$ \\
\hline $\begin{array}{l}\text { Significance } \\
\text { Gas } \\
\text { (high) } \\
\text { Significance }\end{array}$ & $\left\{\begin{array}{l}\text { No } \\
\text { Yes }\end{array}\right.$ & $\begin{array}{r}299 \\
73\end{array}$ & $\begin{array}{l}44 \\
43\end{array}$ & $\begin{array}{l}44 \\
43\end{array}$ & $\begin{array}{r}166 \\
17\end{array}$ & $\begin{array}{l}52 \\
60\end{array}$ & $\begin{array}{l}52 \\
60\end{array}$ \\
\hline $\begin{array}{l}\text { Heat } \\
\text { Significance }\end{array}$ & $\left\{\begin{array}{l}\text { No } \\
\text { Yes }\end{array}\right.$ & $\begin{array}{r}354 \\
18\end{array}$ & $\begin{array}{l}43 \\
49\end{array}$ & $\begin{array}{l}44 \\
50\end{array}$ & $\begin{array}{r}122 \\
61\end{array}$ & $\begin{array}{l}51 \\
56\end{array}$ & $\begin{array}{l}51 \\
56\end{array}$ \\
\hline
\end{tabular}

tSee footnote table 1.

None of the differences between pairs was significant at the $10 \%$ level. 
Table 7 Spirometric changes according to gas and heat exposure (excluding men who quit or decreased smoking 1960-72)

\begin{tabular}{|c|c|c|c|c|c|c|c|}
\hline & & \multicolumn{6}{|c|}{ Noticeable dust } \\
\hline & & \multicolumn{3}{|l|}{ No } & \multicolumn{3}{|l|}{ Yes } \\
\hline & & $N o$ & $\begin{array}{l}\text { FEV slope } \\
(\mathrm{ml} / \mathrm{a})\end{array}$ & $\begin{array}{l}\text { ASLA† } \\
F E V \text { slope } \\
(m l / a)\end{array}$ & No & $\underset{(m l / a)}{F E V \text { slope }}$ & $\begin{array}{l}A S L A \dagger \\
F E V_{1} \text { slope } \\
(M l / a)\end{array}$ \\
\hline Gas & $\left\{\begin{array}{l}\text { No } \\
\text { Yes }\end{array}\right.$ & $\begin{array}{l}174 \\
139\end{array}$ & $\begin{array}{l}43 \\
43\end{array}$ & $\begin{array}{l}45 \\
45\end{array}$ & $\begin{array}{l}85 \\
68\end{array}$ & $\begin{array}{l}51 \\
53\end{array}$ & $\begin{array}{l}53 \\
53\end{array}$ \\
\hline $\begin{array}{l}\text { Significance } \\
\text { Gas } \\
\text { (high) } \\
\text { Significance }\end{array}$ & $\left\{\begin{array}{l}\text { No } \\
\text { Yes }\end{array}\right.$ & $\begin{array}{r}257 \\
56\end{array}$ & $\begin{array}{l}44 \\
41\end{array}$ & $\begin{array}{l}46 \\
42\end{array}$ & $\begin{array}{r}139 \\
14\end{array}$ & $\begin{array}{l}51 \\
65\end{array}$ & $\begin{array}{l}51 \\
67 \\
\bullet\end{array}$ \\
\hline $\begin{array}{l}\text { Heat } \\
\text { Significance }\end{array}$ & $\left\{\begin{array}{l}\text { No } \\
\text { Yes }\end{array}\right.$ & $\begin{array}{r}297 \\
17\end{array}$ & $\begin{array}{l}43 \\
53\end{array}$ & $\begin{array}{l}44 \\
55\end{array}$ & $\begin{array}{r}101 \\
52\end{array}$ & $\begin{array}{l}53 \\
57\end{array}$ & $\begin{array}{l}51 \\
58\end{array}$ \\
\hline
\end{tabular}

$\bullet p=0.09$.

†See footnote table 1.

high level of gas, a trend appeared in the subgroup of men exposed to dust (ASLA FEV, slopes were 61 $\mathrm{ml} / \mathrm{a}$ for the exposed $v 52 \mathrm{ml} / \mathrm{a}$ for the non-exposed). Excluding then men who quit or decreased smoking in the 1960-72 period (table 7), the FEV slope of men exposed to dust and a high level of gas decreased by $16 \mathrm{ml} / \mathrm{a}$ more than that of those

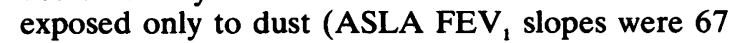
$\mathrm{ml} / \mathrm{a} v 51 \mathrm{ml} / \mathrm{a} ; \mathrm{p}=0.09$ ). The significance was only of borderline significance but one group was small.

In summary, a difference between men exposed and not exposed to gases appeared to show up (1) when the level of exposure was high and (2) only in the presence of simultaneous exposure to noticeable dust.

\section{Heat}

The same analysis showed that men exposed to heat, whatever their exposure to dust, had higher ASLA FEV , slopes than men not exposed to heat (tables 6 and 7). Excluding men who quit or decreased smoking, FEV 1 slopes adjusted for age, smoking, level of and exposure to dust were $49 \mathrm{ml} / \mathrm{a}$ for the men not exposed and $57 \mathrm{ml} / \mathrm{a}$ for those exposed to heat $(\mathrm{p}=0.06)$.

Almost all men exposed simultaneously to noticeable dust and a high concentration of gases were also exposed to heat: it was, therefore, not possible to determine if it was dust or heat or both that was the factor added to gas to give it a deleterious effect.

From all these results, a variable "exposure synthesis" was defined as follows: no exposure or exposure only to a slight amount of dust or only to gases (0), exposed to noticeable dust (D), exposed to heat $(\mathrm{H})$, exposed to noticeable dust and heat (DH), and exposed to noticeable dust, high concentration of gas, and heat (DGH). Five men only were exposed to another combination of risks - that is, high level of gas associated to either heat or noticeable dust and were excluded. ASLA FEV 1 slopes were respectively $44 \mathrm{ml} / \mathrm{a}, 51 \mathrm{ml} / \mathrm{a}, 53 \mathrm{ml} / \mathrm{a}, 55 \mathrm{ml} / \mathrm{a}$, and $60 \mathrm{ml} / \mathrm{a}$ in the whole population $(p=0.02)$. Excluding men who quit or decreased smoking, ASLA FEV , slopes were $44 \mathrm{ml} / \mathrm{a}, 50 \mathrm{ml} / \mathrm{a}, 59 \mathrm{ml} / \mathrm{a}$, $56 \mathrm{ml} / \mathrm{a}$, and $67 \mathrm{ml} / \mathrm{a}(\mathrm{p}=0.02)$.

\section{SOCIO-OCCUPATIONAL CLASS}

Taking simultaneoulsy into account sociooccupational class and occupational exposure was possible only for manual workers because of the small number of exposed managers and clerks. Unskilled workers were not exposed more often than skilled manual workers $(79 \% v 77 \%)$ but they were significantly more often exposed to the hazards shown to be the most noxious. Whereas the percentage of unskilled manual workers was $49 \%$ in the whole sample, it was according to the exposure synthesis $38 \%(\mathrm{O}), 57 \%(\mathrm{D}), 86 \%(\mathrm{H}), 75 \%(\mathrm{DH})$, and $60 \%(\mathrm{DGH})(\mathrm{p}<0.001)$. Exposure to heat was three times more frequent for unskilled than for skilled manual workers. Figure 2 presents the ASLA FEV , slopes according to qualification for each exposure class. The exposure synthesis adjusted values were $51 \mathrm{ml} / \mathrm{a}$ for unskilled and $44 \mathrm{ml} / \mathrm{a}$ for skilled $(p=0 \cdot 03)$. After adjustment for sociooccupational class, the ASLA slopes became by exposure synthesis $44 \mathrm{ml} / \mathrm{a}(\mathrm{O}), 49 \mathrm{ml} / \mathrm{a}(\mathrm{D}), 67 \mathrm{ml} / \mathrm{a}$ $(\mathrm{H}), 54 \mathrm{ml} / \mathrm{a}(\mathrm{DH})$, and $60 \mathrm{ml} / \mathrm{a}(\mathrm{DGH})(\mathrm{p}=0 \cdot 17)$. Excluding men who quit or decreased smoking, the slopes became respectively $51 \mathrm{ml} / \mathrm{a} v 45 \mathrm{ml} / \mathrm{a}$ by qualification after adjustment for exposure $(p=0.05)$ and $45 \mathrm{ml} / \mathrm{a}(\mathrm{O}), 48 \mathrm{ml} / \mathrm{a}(\mathrm{D}), 70 \mathrm{ml} / \mathrm{a}(\mathrm{H})$, $54 \mathrm{ml} / \mathrm{a}(\mathrm{DH})$, and $66 \mathrm{ml} / \mathrm{a}(\mathrm{DGH})$ by exposure after adjustment for qualification $(p=0 \cdot 10)$. This difference is just of borderline significance, but several classes contained very few men. 


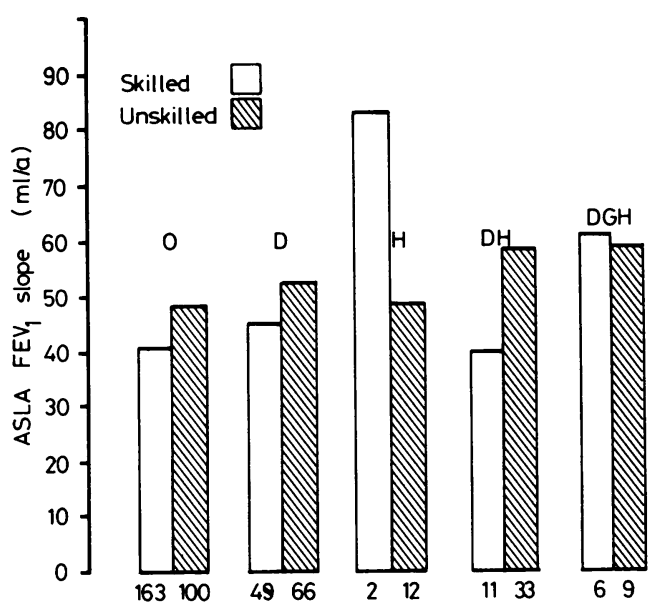

Fig 2 Age, smoking habits, and level adjusted (ASLA) $F E V$, slope according to occupational exposure and occupational qualification (manual workers). O: No exposure or only to a slight amount of dust or only to gases. D: Noticeable dust. H: Heat. G: High concentration of gases. Number of men is figured under each bar.

\section{FACTORY}

Large differences in $\mathrm{FEV}_{1}$ slope were observed between factories (table 1). Since the exposure synthesis and socio-occupational classes were significantly different among the factories, an analysis was made to see if these differences could explain the differences in the slopes. Table 8 presents the percentage of the variance in $\mathrm{FEV}_{1}$ slope explained in a model where the various factors were introduced in succession from better to less well known: FEV, level and smoking explained $7.8 \%$ of the variance; introducing silica, exposure synthesis and socio-occupational class explained $10.0 \%$ of the variance. Finally,

Table 8 Factors related to FEV, slope

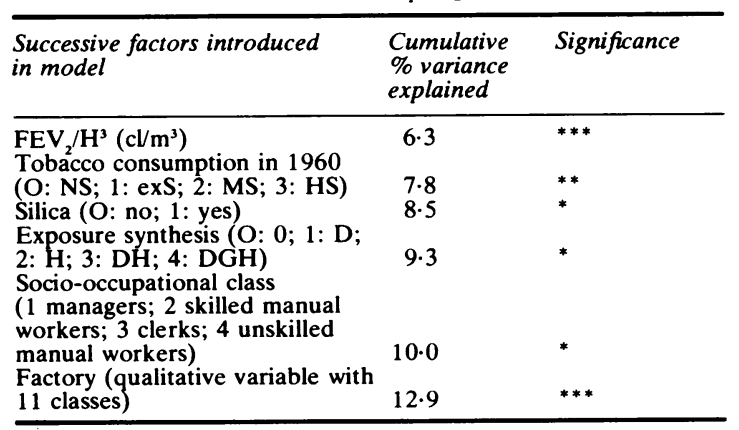

$\mathrm{O}$ : No exposure or only to a slight amount of dust or only to gases. D: Noticeable dust.

H: Heat.

G: High concentration of gases.

${ }^{*} \mathrm{p} \leqslant 0.05,{ }^{* *} \mathrm{p} \leqslant 0.01,{ }^{* * *} \mathrm{p} \leqslant 0.001$ introducing the variable "factory" explained $2.9 \%$ more $(p<0.001)$. Therefore, the factor factory was significantly related to $F E V$, slope independently of socio-occupational class and occupational exposure.

\section{CHANGE OF WORK}

Since the reasons for job changes differ in manual and non-manual workers, only the former were considered in this section. Table 9 presents spirographic measurements according to job changes between the two surveys.

\section{Medical reasons}

Compared with the rest of the men, those who changed workplace or factory for medical reasons were older in 1960, but, after adjustment for age, did not have significantly lower $\mathrm{FEV}_{1}$ s. Nevertheless, the decline of FEV 1 as well as of VC observed over the 12-year period was significantly steeper; in the subgroup of men who changed for respiratory reasons, the mean $F E V_{1}$ slope exceeded $80 \mathrm{ml} / \mathrm{a}$.

\section{Other reasons}

Compared with men who did not change jobs, those who changed for reasons not related to health (137 changed workplace, 46 changed factory, and one became unemployed) were younger in 1960 and their $F E V_{1} s$ were higher, even after adjustment for age, but their $F E V_{1}$ slopes were not significantly different, at least on the whole, without considering occupational exposure.

We did not have information about occupational exposure after job change: nevertheless, men initially heavily exposed were probably less exposed on average after the change than before, whereas the exposure of the men not or slightly exposed did not change or even increased a little. Thus, considering separately men who initially were not or were

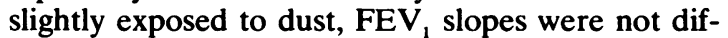
ferent between those who changed and those who did not $(43 \mathrm{ml} / \mathrm{a} v 41 \mathrm{ml} / \mathrm{a})$. By contrast, for noticeably exposed men, there was an important difference $(42 \mathrm{ml} / \mathrm{a} v 56 \mathrm{ml} / \mathrm{a} ; \mathrm{p}<0.01)$. ASLA FEV slopes became $45 \mathrm{ml} / \mathrm{a} v 53 \mathrm{ml} / \mathrm{a}(\mathrm{p}=0 \cdot 13)$. ASLA VC slopes were respectively $34 \mathrm{ml} / \mathrm{a} v 44 \mathrm{ml} / \mathrm{a}$ $(p=0.03)$. The difference was not significant for the FEV $_{1}$ slope, but, as shown in discussion, the test used here was not the most powerful, and the trend is clear. These results show that FEV ${ }_{1}$ loss and VC loss for the men who are believed to have reduced their occupational exposure was lower than the loss for those whose exposure continued unchanged; this is another argument in favour of the causal role of this exposure. The 18 manual workers initially most exposed (noticeable dust degree 3 ) were particularly striking in this respect: the 11 who changed their 
Table 9 Spirometric changes according to job changes and occupational exposure (manual workers only)

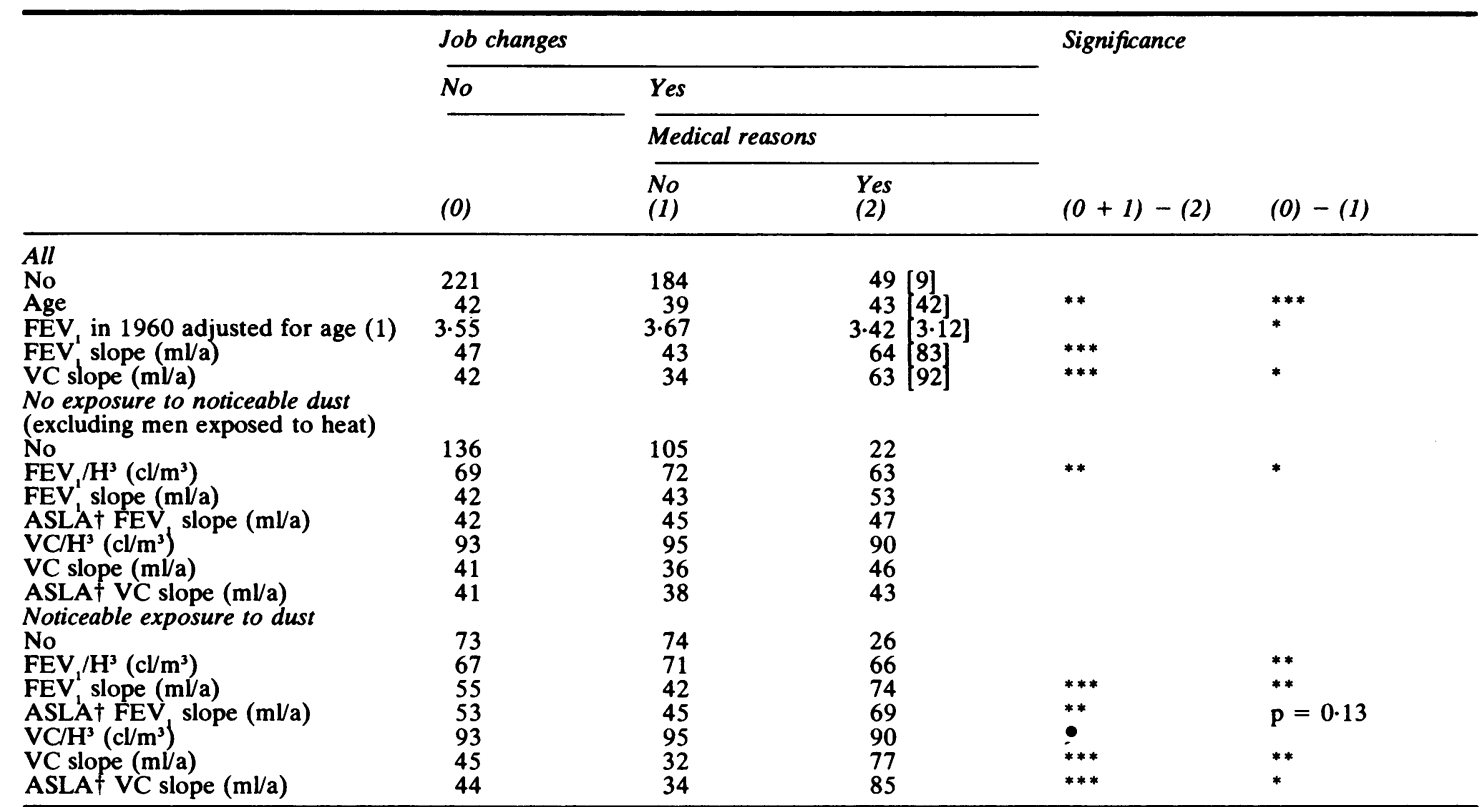

-p $\leqslant 0 \cdot 10,{ }^{*} \mathrm{p} \leqslant 0 \cdot 05,{ }^{* *} \mathrm{p} \leqslant 0.01,{ }^{* * *} \mathrm{p} \leqslant 0.001$.

[]: Respiratory illnesses.

tSee footnote table 1 .

work had in 1960 a FEV lower on average than the seven who did not change $(3.451 v 3.481)$ but higher in $1972(2.971 v 2.91 \mathrm{l})$. Such an analysis was not possible for risks other than dust because the number of men was too small.

Figure 3 presents $F E V_{1}$ and $V C$ slopes for each of the three groups (no job change, changes for medical reasons, and changes for other reasons) according to exposure to dust and $F E V_{1}$ and VC levels during the study. Among the men originally exposed, those who changed for medical reasons* had a significantly steeper FEV ${ }_{1}$ slope than those in the other two groups, although they withdrew from exposure. It seems likely that their $\mathrm{FEV}_{1}$ s were so degraded that the effect of withdrawal from risk during the period had only a minor effect.

\section{Discussion}

Whereas most studies question the influence of exposure to dust, with the exception of vegetable dust $^{15}$ on chronic airflow obstruction, our follow-up study clearly showed that mineral as well as veget-

\footnotetext{
*The three men who changed because of recognised silicosis had FEV,$s$ in 1960 of $3.761,4.471$, and 3.351 at ages 38,43 , and 35 years, which decreased during the period $1960-72$ by $63 \mathrm{ml} / \mathrm{a}, 177$ $\mathrm{ml} / \mathrm{a}$, and $229 \mathrm{ml} / \mathrm{a}$, whereas their job changes took place respectively in 1964, 1964, and 1971.
}

able dust were risk factors for CAO. It showed that exposure to heat was associated with a steeper FEV slope and suggested that exposure to gases when combined with exposure to dust or heat or both might accelerate FEV 1 loss. Furthermore, low occupational status and specific factory appeared, independent of occcupational exposure, as risk factors for CAO.

Concerning dust, the causal hypothesis of this risk factor in the development of CAO is supported by the three following results:

(a) Men exposed to dust had a steeper FEV slope than those not exposed even in the absence of exposure to silica.

(b) The slope increased with the intensity of exposure.

(c) A decrease of this slope was observed among heavily exposed men who changed their jobs (thus less exposed in a certain proportion to risk). This suggests also that the acceleration of $\mathrm{FEV}_{1}$ loss due to exposure to dust is, at least partially, reversible.

Numerous cross-sectional surveys have studied the role of dust, many of them being comparisons of miners with workers in a non-dusty atmosphere. Most of these studies did not show significant differences in ventilatory variables, but, as underlined by Gilson, ${ }^{6}$ there was in nearly all of the studies a striking uniformity of pattern-exposed subjects had 
No exposure to noticeable Noticeable exposure to dust dust (excluding men exposed to heat)

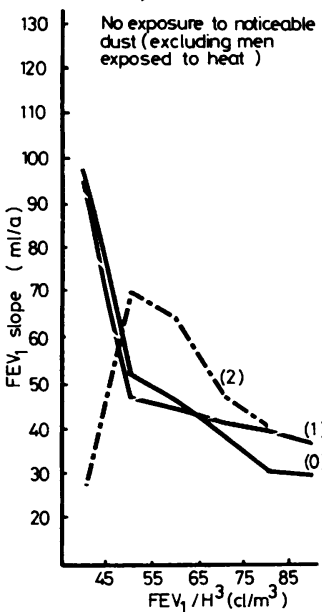

$(0+1)-(2) \mathrm{p}=0.42$

(0) $-(1) \mathrm{p}=0.48$

$(0+1)-(2) p=0.42$ (0) $-(1) p=0.48$

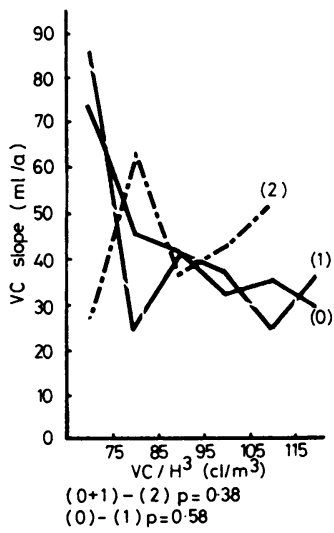

$(0+1)-(2) \mathrm{p}=0.38$

(0) $-(1) \mathrm{p}=0.58$

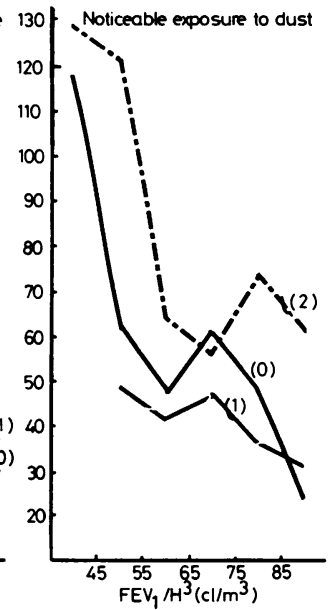

$(0+1)-(2) \mathrm{p}=0.002$

(0) $-(1) p=0.065$

$(0+1)-(2) p=0.002$
$(0)-(1) p=0.065$

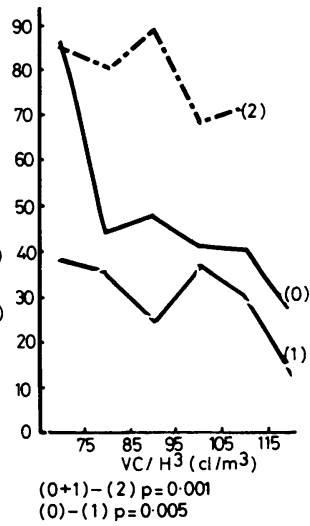

$(0+1)-(2) \mathrm{p}=0.001$

(0) $-(1) \mathrm{p}=0.005$

Fig $3 F E V$, and $V C$ slopes versus $F E V_{1} / H^{3}$ and $V C / H^{3}$ levels according to occupational exposure and job changes (manual workers). - 0 No job change. -..- 2 Change for medical reasons. - 1 Change for other reasons.

lower values than controls.

The smallness of the differences observed by others in cross-sectional surveys may be explained by the fact that all negative studies were conducted among working subjects. This type of study provides clear information on exposure, but, although often considered by different authors, the magnitude of the problem of the selection of the subjects working in an exposed workplace ("healthy worker effect") has been underestimated. We also found in our cross-sectional survey in $1960,{ }^{3}$ when all the men were working, that no relationship was shown be-

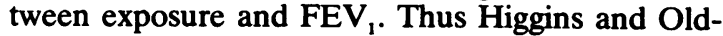
ham $^{7}$ in a study conducted among working miners were not able to show a relationship between ventilatory function and duration of work at coalface (another possible quantification of occupational exposure). Lowe and Khosla, ${ }^{8}$ however, studying ex-miners, showed a strong relationship between the level of $\mathrm{FEV}_{1} / \mathrm{VC}$ and the duration of work in the mines. The study of Rogan et al ${ }^{9}$ who showed a highly significant dose-related effect between ageadjusted cumulative dust exposure (intensity $\times$ duration) and $\mathrm{FEV}_{1}$ was conducted at one and the same time on present and former coalface workers. From the results of our follow-up study, it appeared that the $\mathrm{FEV}_{1}$ was higher in the exposed group aged around 35 and decreased with a steeper slope to reach lower values at the age of retirement.

Only one study ${ }^{10}$ was conducted on a general population. The subjects were interviewed on the risks to which they had been exposed, but only certain risks could be studied because of the few subjects exposed to the other risks. It appeared that a lower

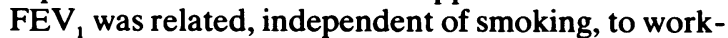
ing with silica, fibreglass, asbestos, smoke, and sawdust. Such a study avoids the problem of healthy worker effect, but diseased subjects are perhaps more likely to report occupational exposure. Such a possible bias does not seem to explain the results of this study since subjects reporting respiratory illnesses in childhood worked significantly less often at exposed jobs. This is an aspect of the selection problem.

Other authors ${ }^{1-9}$ think that the absence of a relationship between symptoms of chronic bronchitis and exposure to dust casts doubt on the validity of the trends observed for ventilatory variables. In the Co-operative German Study ${ }^{11}$ data were mainly analysed using a model combining classification of four "clinical types" (symptoms assessed by the BMRC/ECSC questionnaire and findings from auscultation) and four functional types of obstructive disorders (function tests and $\mathrm{PaO}_{2}$ measurements). Chronic bronchitis, however, is no longer considered to be the first stage of chronic airflow obstruction, but is thought to be a parallel disease with common risk factors. ${ }^{251213}$ Morgan, ${ }^{14}$ although considering this notion of two parallel diseases, suggested that CAO due to dust, in contrast with that due to smoking, begins in the large airways. The situation may indeed be different for tobacco smoke and dust, for industrial dust, unlike tobacco smoke, is not composed only of respirable particulates easily reaching the small airways but also of a non-respirable fraction, which could 
theoretically initiate lesions only in the large airways. No study recorded respirable and nonrespirable particles separately, although such a study might provide revealing differences in the respective natural histories of pneumoconiosis, emphysema, and diseases of the small and large airways.

Few follow-up studies have been conducted on this topic. To our knowledge, except for studies on miners, there have been only four follow-up studies on the role of industrial dust. Casula $e a{ }^{15}$ in a follow-up study over three years came to no conclusion but there were only 72 subjects, and the authors may have introduced a bias by analysing only subjects with "coherent" answers to the two questionnaires. Brinkman et al ${ }^{16}$ over 11 years did not find any effect of dust, but only $33 \%$ of those not known to be dead were re-examined in the second survey, and it seems that they were mainly the men still at work at the end of the period-that is, with the same selection problem that bedevils cross-sectional surveys. By contrast, Jedrychowski ${ }^{17}$ in a follow-up study conducted over five years showed a significantly steeper decrease of $\mathrm{FEV}_{1}$ among subjects exposed to dust than in controls, more clearly in smokers, but there were few non-smokers. Similarly, Pham et al ${ }^{18}$ in a follow-up study over five years showed significant differences in the evolution of $\mathrm{FEV}_{1}, \mathrm{FEV}_{1} / \mathrm{VC}$, residual volume/total capacity, and fractional uptake of $\mathrm{CO}$ between heavily exposed founders and non-exposed men. The phenomenon of selection was clearly shown in their study: the exposed men had, in the first survey, higher spirographic values than the non-exposed. Active workers in the factory of origin as well as those who left were re-examined in this study.

Several aspects of the methods we used allowed us to obtain our results. The study was longitudinal, and after a long period (12 years) a search was made for all the men, including those not at the same workplace at the time of the second survey as well as those who were. The study of the workplace was done independently of the subjects and before the measurements of $\mathrm{FEV}_{1}$ slope. Nevertheless, we regret that no really quantative measurement was made of occupational exposure and that changes in exposure during the period were not recorded.

One of the arguments supporting the causal character of exposure to dust in the development of CAO was based on the demonstration of the effect of change of work, which indirectly indicates changes in exposure. Being able to take into account the possible initial selection of the subjects and the study of changes in risk factors are two major advantages of follow-up compared with cross-sectional studies. To our knowledge, such data have never been analysed in the field of occupational exposure: the problem is quite complex and has been approached only in part. ${ }^{1920}$ The problem is to test on longitudinal data whether the FEV, slopes before and after change in risk factor are different, taking into account two elements-firstly, the correlation existing between level and slope (described by Fletcher $e a^{12}$ as analogous to a horse racing effect) and, secondly, the fact that subjects who have a decrease in the risk factor under study are not comparable with the others. On this last point, the problems of smoking and occupational exposure differ: whereas subjects who quit smoking had, before stopping, a lower FEV $_{1}$ than other smokers, ${ }^{21}$ heavily exposed men who changed workplace had a higher initial FEV than the others (table 9). The adjustment made here on $F E V_{1} / \mathrm{H}^{3}$ level reached during the study was intended to correct for the disparity between the two groups (with and without the change): to eliminate the phenomenon of regression toward the mean, the mean level over the period was used. It was calculated assuming a linear $\mathrm{FEV}_{1}$ decrease between the two surveys, when we really want to show there is a "break" for the group with change; thus the method used was not the most powerful, but despite this the differences observed were still significant for VC slope.

It is not possible from our study to incriminate specific dust components. Indeed, except for silica, we were not able to identify another type of mineral dust as noxious. Exposure to grain dust appeared to be related to particularly steep slopes, which explains why this risk factor was found, as was silica, in cross-sectional surveys. ${ }^{22} \mathrm{~A}$ recent symposium ${ }^{22}$ devoted to this subject raised the question of whether the responsible constituent(s) were organic or inorganic.

Concerning gases, vapours, and aerosols, differences were observed between those exposed and non-exposed for gases in general, and for oil of turpentine and non-halogenated hydrocarbons. Taking into account other risks, results suggest that a high level of exposure to gases had a deleterious effect when associated with exposure to noticeable dust or to heat or to both. Experimental studies suggest that particulate aerosols are more biologically reactive than gases alone, as it has been shown for $\mathrm{SO}_{2}{ }^{23}$ and that heat could increase the diffusion of aerosols. ${ }^{24}$ Our results support such hypotheses. A few men were exposed to each risk, and it was not possible to study each gas exposure according to the presence of dust. There have been toxicological studies of the effects of chemical products, but few studies of the chronic effects of gases on the respiratory tract, and we know of none on the effects of oil of turpentine. Results on non-halogenated hydrocarbons may be compared with the results of Lebowitz ${ }^{10}$ on solvents 
in general. A clear trend was observed regarding the influence of heat on $\mathrm{FEV}_{1}$ decline. Musk et $\mathrm{l}^{25}$ in a follow-up study over three years among active firemen did not show a relationship between decreases of ventilatory function and the number of fires, but their data suggest that the most heavily exposed subjects were a self-selected group: the men with the greatest exposure had on average the highest FEV 1 levels, and the analysis of FEV slope did not take this into account. Sartorelli et al ${ }^{26}$ in a cross-sectional survey among heavily exposed pyrite miners, concluded that lower lung function was partly attributable to a hot humid microclimate with pronounced thermal gradients. Our results may also be compared with those of Fine et $\mathrm{l}^{27}$ who showed a steeper FEV 1 decrease over one year among rubber-curing workers exposed simultaneously to dust and gases in a heated atmosphere.

In addition to the occupational risk factors, two socio-occupational factors appeared to be related to FEV 1 decline: low occupational status and factory. Low occupational status appeared as a risk factor, independent of occupational exposure. In contrast to Higgins's results ${ }^{28}$ differences in smoking habits between social classes did not explain the differences observed. Our results agree with those of Cohen $e t a^{29}$ who showed a relationship between a decreased $\mathrm{FEV}_{1}$ and area of residence, interpreted as a social class indicator, and with those of Higgins ${ }^{30}$ where it appeared that the wives of miners had lower $F E V_{1} s$ which, in the absence of occupational exposure, may be interpreted as an economic or cultural factor.

The factory appeared in this study as a risk factor in its own right, independent of our estimates of occupational exposure and of socio-occupational class. Probably an inaccurate assessment of risk partially explains the difference observed; our indices of risk pooled various exposures because of the extreme diversity among the products used in the 11 factories studied. Moreover, data were collected at one moment with no real quantitative measurements. Additional data on physical and mental effort and on the psychosociological conditions of the work place might have permitted better evaluation of this factor. ${ }^{31}$ The differences we showed between factories underline the problems raised by those studies in which comparisons between exposed and non-exposed subjects are made in only two exposure-contrasted factories.

In conclusion, further studies of the role of occupational exposures in the development of CAO are clearly needed. I would be desirable (1) to measure the real exposure in the work place directly, and to do physicochemical analyses of mineral and grain dust and (2) to avoid the problem of selection either by follow-up studies, where the same subjects are examined twice, or possibly by recording ventilatory measurements only once, but relating these to previous-for example, 10 years before the studyrather than to present exposure. Perhaps some of the biases inherent in the collection of such retrospective data on work conditions can be eliminated by using the factory's own documents.

We are grateful to $\mathrm{J} C$ Hinglais who performed the study of workplace, to the medical services of the factories, to M Gysin, M M Hamelin, and M Maheu, social workers, G Lapeyre, A Dernoncourt, G Demay, and D Parmentier for the secretarial part of the survey, L Labbat for help in the spirographic measurements, the observers and coders of the two surveys, and the men who have participated in the study. We thank also J Zalokar for help in translation and $M$ Sevin and $D$ Salomon for typing the manuscript, and the reviewers for their comments.

Supported by grants from the European Coal and Steel Community (ECSC), the Caisse Nationale d'Assurance Maladie des Travailleurs Salariés (CNAMTS), and the Institut National de la Santé et de la Recherche Médicale (INSERM).

\section{References}

' Higgins ITT. Epidemiology of chronic respiratory disease: a literature review. Washington DC: 1974. (Environmental health effects research series EPA 650/1.74.007).

${ }^{2}$ Kauffmann F, Drouet D, Lellouch J, Brille D. Twelve years spirometric changes among Paris area workers. Int J Epidemiol 1979;8:201-12.

${ }^{3}$ Kourilsky R, Brille D, Hatte J, Carton J, Hinglais JC. Enquête sur l'étiologie et la prophylaxie de la bronchite chronique et de l'emphysème pulmonaire. Paris: Caisse Régionale de la Sécurité Sociale de Paris, 1966.

4 Bolt W, Brille D, Cara M, et al. Aide-mémoire pour la pratique de l'examen de la fonction ventilatoire pour la spirographie. Luxembourg: Commission of the European Communities, 1967:67. Collection d'Hygiène et de Médecine du travail, No14.

${ }^{5}$ Speizer FE, Tager IB. Epidemiology of chronic mucus hypersecretion and obstructive airways disease. Epidemiol Rev 1979;1:124-42.

- Gilson JC. Occupational bronchitis? Proc $R$ Soc Lond 1970;63:857-64.

' Higgins ITT, Oldham PD. Ventilatory capacity in miners. A five-year follow-up study. Br J Ind Med 1962;19:65-76.

${ }^{8}$ Lowe CR, Khosla T. Chronic bronchitis in ex-coal miners working in the steel industry. Br J Ind Med 1972;29:45-9.

' Rogan JM, Attfield MD, Jacobsen M, Rae S, Walker DD, Walton WH. Role of dust in the working environment in development of chronic bronchitis in British coal miners. Br J Ind Med 1973;30:217-26.

${ }^{10}$ Lebowitz MD. Occupational exposures in relation to symptomatology and lung function in a community population. Environ Res 1977;14:59-67.

"Valentin H, Smidt U. Research report chronic bronchitis and occupational dust exposure. Cross-sectional study of occupational medicine on the significance of chronic inhalative burdens for the bronchopulmonary system. Boppard: Boldt, 1978. 
${ }_{12}$ Fletcher C, Peto R, Tinker C, Speizer FE. The natural history of chronic bronchitis and emphysema. Oxford: Oxford University Press, 1976.

${ }^{13}$ Fletcher CM, Peto R. The natural history of chronic airflow obstruction. Br Med J 1977;i: 1645-8.

14 Morgan WKC. Industrial bronchitis. $\mathrm{Br} \mathrm{J}$ Ind Med 1978;35:285-91.

15 Casula D, Carta P, Flore C, Sanna-Randaccio F. Changes in respiratory symptoms in the pulmonary function in a 3-year follow-up study of dust exposed workers. Bronchopneumologie 1978;28:463-78.

${ }^{16}$ Brinkman GL, Block DL, Cress E. Effects of bronchitis and occupation on pulmonary ventilation over an 11-year period. JOM 1972;14:615-20.

17 Jedrychowski W. A consideration of risk factors and development of chronic bronchitis in a five-year follow-up study of an industrial population. $J$ Epidemiol Community Health 1979;33:210-4.

${ }^{18}$ Pham QT, Mastrangelo G, Chau N, Haluska J. Five year longitudinal comparison of respiratory symptoms and function in steel workers and unexposed workers. Bull Eur Physiopathol Respir 1979;15:469-80.

${ }^{19}$ Hsu PH, Mathewson FAL, Hassan AH, Zeid A. Change in risk factor and the development of chronic disease. A methodological illustration. J Chronic Dis 1977;30:567-84.

${ }^{20}$ Rosner B. The analysis of longitudinal data in epidemiologic studies. J Chronic Dis 1979;32:163-73.

${ }^{21}$ Kauffmann F, Querleux E, Drouet D, Lellouch J, Brille D. Evolution du VEMS en 12 ans et tabagisme chez 556 travail- leurs de la région parisienne. Bull Eur Physiopathol Respir 1979;15:723-37.

${ }^{22}$ Cotton DJ, Dosman JA. Grain dust and health. III Envionmental factors. Ann Intern Med 1978;89:420-1.

${ }^{23}$ American Thoracic Society. Health effects of air pollution. New York: American Lung Association, 1978.

${ }^{24}$ Brain JD, Valberg PA. Deposition of aerosol in the respiratory tract. Am Rev Respir Dis 1979;120:1325-73.

${ }^{25}$ Musk AW, Peters JM, Wegman DH. Lung function in fire fighters. $1 \mathrm{~A}$ three year follow-up of active subjects. Am J Public Health 1977;67:626-9.

${ }^{26}$ Sartorelli E, Lo Martire N, Franzinelli A, Zedda S, Gervasini N, Scotti P. Indagine epidemiologica sulla bronchite cronica nei minatori di pirite. Med lav 1969;60:413-32.

${ }^{27}$ Fine LJ, Peters JM. Respiratory morbidity in rubber workers. 2 Pulmonary function in curing workers. Arch Environ Health 1976;31:6-10.

${ }^{28}$ Higgins MW, Keller JB, Metzner HL. Smoking, socio-economic status and chronic respiratory disease. Am Rev Respir Dis 1977;116:403-10.

${ }^{29}$ Cohen BH, Ball WC, Brashears S, et al. Risk factors in chronic obstructive pulmonary disease (COPD). Am J Epidemiol 1977;105:223-32.

${ }^{30}$ Higgins ITT. Chronic respiratory disease in mining communities. Ann NY Acad Sci 1972;200:179-210.

${ }^{31}$ Guelaud F, Beauchesne MN, Gautrat J, Rousang G. Pour une analyse des conditions du travail ouvrier dans l'entreprise. Paris: A Colin, 1975. 